\title{
Law, State and Religious Freedom in Brazil: A Historical and Constitutional Analysis of Freedom of Belief and Religion
}

\author{
By Micael Fernandes Gomes dos Santos* \& \\ Michely Vargas Delpupo Romanello ${ }^{ \pm}$
}

\begin{abstract}
This research sees to discuss the position of the State regarding Freedom of Belief, under the legal perspective. In other words, as the Brazilian Constitution guarantees freedom and the free exercise of religion in its art. 5, item VI, the question is: May the Brazilian State interfere with the freedom of individual belief, or can it provide legal guarantees so that this freedom is ensured? By the deductive method and by the analysis of recent judgments of the Brazilian Federal Supreme Court in cases of extraordinary appeals, the limits of the State of action or inaction in relation to religious freedom will be upheld, concluding that the State must always ensure the sovereignty of secularity and neutrality in religious matters, observing freedom of belief.
\end{abstract}

Keywords: Religious freedom; Brazilian State; Law

\section{Introduction}

"[...] Give, therefore, to Caesar what belongs to Caesar and to God what belongs to God". (Matthew 22:21).

From this biblical text, it is possible to infer the antiquity that occurs when the theme is the relationship between State and Church. Now, for a long time, as can be seen from history, this relationship was corroborated by disturbed acts and agreements that aimed at the inquisitive and non-sensory power. In other words, the State-religion relationship was aimed at the practices of power and inquisition, leaving no reserves of individual beliefs capable of enjoying freedom of thought.

It is important to highlight that the construction of a society is based on congruent and divergent factors, and the thought is not uniform when the theme is religion. Should the State then, in view of its sovereignty, use law as a vehicle and tool capable of equalizing divergent relations? Now, it is known that the law is a full and direct instrument, capable of settling controversies and minimizing litigation of the most diverse agendas. However, how could it be applied in the State vs. religion litigious extinction?

Religion, as an individual or collective guarantee of conscience. Based and wrapped up in the democratic rule of law, it is shaped by the faithful conduct, or

\footnotetext{
*Law Graduate, University Adventist Center of São Paulo, São Paulo, Brazil \& Intern at Zanin Business Advocacy. Email: micaelfernandes000@gmail.com

${ }^{ \pm}$Lawyer and Professor of Civil Law, Pontifical Catholic University of São Paulo, São Paulo, Brazil. Email: michelydelpupo@terra.com.br
} 
not, of the individual who turns to grows and liturgies that he wants. From this, it is known that, in order to have a legal guarantee, there must be a state legislative action in order to settle and settle disputes that involve the will to believe or simply not to believe, which makes the direct activity of the State evident.

This time, both the State and the religions have rules of conduct. Reconciling them is a fine line, as this requires interference by the state in the church or by the church in the state. In other words, from the moment that the individual, seeking his constitutional guarantees, turns to the democratic State of law, this, in a positive way, must exercise the activity of ensuring such rights.

In view of this, the question is: would state activity in the preservation of freedom of belief and religion be an affront to the constitution, since interference in religious matters is prohibited? And yet, how do fundamental rights fit into the state's obligation to protect minorities?

It is important to highlight the role that the State plays, through legislative and judgmental politicisation, since it tries to demonstrate the State's non-secularity, but, in a correct way, its neutrality in the way of judging; to interfere when necessary to protect individual rights; and to legislate. Such neutrality is mainly designed to guarantee the rights of the most inaccessible minorities, as will be analysed in the recent judgment on freedom of belief involving Seventh-day Adventists.

This time, the historical analysis of religious freedom is of great importance. Observing the social and legal difficulties that this one went through until reaching the constitutional guarantee that we have today. It also seeks to discuss state secularity, religious equality and analysis of jurisprudence.

Based on such propositions, this research uses the so-called deductive reasoning as a scientific method to guide its questions. The choice of such method was based on the fact that it was outlined as the most suitable for the discussions presented here. In this sense, we start from general premises and propositions for particulars; or of arguments that are considered to be true and unquestionable and then reach formal conclusions.

Given the bibliographic character of the research, the investigation techniques were centred on books, articles specialised in the subject, periodicals, theses and dissertations, legislation and pertinent jurisprudence.

\section{Historical Developments of Freedom of Belief}

In this topic, a little of the historicity of religious freedom will be treated, bringing its historical precedents and social emergence. It is extremely important to study this topic since fundamental freedoms emerged from social factors widely experienced and witnessed by Christian, Evangelical, Catholic or simply atheists.

Thus, human beings have always had the need to create images, symbols and models that could translate their reality and give concrete meaning to their actions. Religion is born as a fundamental subterfuge of the practice of believing, or not in something specific or general. So, talking about religion in a historical character 
denotes the whole story, as it has always been present, intrinsically or extrinsically, in the daily life of society ${ }^{2}$.

Nevertheless, the Jewish faith and life are based on the will of God, His scriptures and teachings. It is not by chance that Christians have inherited Jewish monotheism, where they deposited their salvation through spiritual conversion through repentance of sins and faith in Jesus Christ. It is noted, in passing, that this belief goes beyond the individual limits of the individual and their free conscience, being dissipated according to the society and the context in which they are inserted. ${ }^{3}$

In this treadmill, the individual conscience which leads someone to believe or not in something, can be seen in two different perspectives. First, there is the individual conscience based on the individual's morals. A set of beliefs and moral standards that delimit their actions. On the other hand, there is an awareness regarding the individual's intellectual capacity, as it starts to review, conceptualise and critically evaluate, being its governing moral code. It is imperative to emphasise that, even though they are different perspectives, there is a logical coherence between them, and at any time in the individual's life, conscience as a moral code proceeds to conscience as a moral capacity ${ }^{4}$.

Thus, religion and belief, inserted in the individual's moral conscience, was not always guided by freedom. In ancient Rome, the fact that devout Christians did not submit to the Catholic creed and demands, as well as non-loyalty to the supreme emperor, validated persecution, destruction of temples and even the death penalty for atheists who did not assume the imposed ideological position for the government 5 .

In this scenario, a very important figure emerges for the evolution of the power of free conscience and creed. Martin Luther, in the exercise of his moral capacity, creates a fissure in truth centred through the Protestant Reformation. He diverged, through his 95 theses, from the doctrinal principles of the Catholic Church, such as the sale of indulgences and the issue of purgatory ${ }^{6}$.

Thus, it is noted that the Protestant reform initiated by Martin Luther and other "reformers" was an important factor in the reconstruction of the individual autonomy of the power of choice, which was in constant litigation between the church and the absolutist power. .

Luther did not intend to break with Rome, but was urged by the Roman Curia, denounced by the Dominicans, coincidentally in charge of the sale of indulgences and the Inquisition. In October 1518, in a discussion with the papal legate in Augsburg he stated that "the authority of the scriptures was superior to that of the pope". In 1519, at Leipzig, he declared that, even if the Council declared him in error, "he would not

\footnotetext{
${ }^{2}$ Port (2003) at 3.

${ }^{3}$ Port (2003) at 3 .

${ }^{4}$ Chiassoni (2017) at 260.

${ }^{5}$ Port (2003) at 3.

${ }^{6}$ Neto (2006) at 19.

${ }^{7}$ Bergara \& Gonçalves (2008) at 02.
} 
withdraw his opinions because he felt obliged to submit to the superior authority of the Scriptures". ${ }^{8}$

Likewise, this reform was not limited to just one person, a very typical figure in the form of government Rome adopted, where all power was concentrated in the pope. Now it became a set of guiding principles that were imperially based on three: The supreme authority of the scriptures; salvation by faith and the priesthood alone. Regarding the last principle, Christians should be real priests of God on earth, missionaries, with the aim of disseminating the scriptures ${ }^{9}$.

In this step, ideals emerge that, later, are postulated within the so-called "first generation rights", in which religious freedom is inserted. Based on the triad "freedom", "equality and "fraternity", symbols of the French flag, the first dimension rights originated from the bourgeois revolts inspiring Enlightenment and unnaturalise doctrines of the 17th and 18th century. Synthesised in civil and political rights, the first dimension rights concern the state abstention and individual freedoms, protected against State oppression that harms this individual right.

As can be seen, the legal advances with the presence of individual and collective guarantees are notorious. Human Rights, in turn, inserted in the "third dimension" right, are born in accordance with the needs of the current society, and its emergence is not linked to the fact of human organisation in a social set, much less because of the worldwide verberation for lack of such guaranteeing norms. Human rights arise according to human evolution and its needs ${ }^{10}$.

In this sense, this fact becomes evident when, after the Second World War, society is obliged to protect diffuse guarantees, with the aim of defending the universality, indivisibility and interdependence of rights against the atrocities experienced in the period. Taking as an analysis the text of the Declaration of Human Rights of December 10, 1948, the protection of fundamental rights is noted and, consequently, the limitation of state power, until then from where all power emanated $^{11}$.

The Enlightenment and the French Revolution are the influential landmarks for the increase of religious freedom within international law. When, clearly, the Declaration provided in its tenth article that "no one can be harassed by their opinions, including religious opinions, as long as their manifestation does not disturb the public order established by law". Inferring from this maxim that such a right was not absolute, since personal manifestation that disturbed public order would be prohibited ${ }^{12}$.

With the discovery of the United States, there was an interest in creating new laws there that escaped European dogmatics. The aim was to bring to the "new continent" more liberal and comprehensive laws. "The Anglo-Saxon Puritans, with the intention of making norms for the USA totally contrary to the country they

\footnotetext{
${ }^{8}$ Neto (2006) at 19.

${ }^{9}$ Teraoka (2010) at 19.

${ }^{10}$ Wermuth \& Schorr (2017) at 825.

${ }^{11}$ Wermuth \& Schorr (2017) at 825.

${ }^{12}$ Martins \& Mituzani (2011) at 230.
} 
came from, had the intention of creating a "more liberal" State, where Human Rights would be protected". 13

In response to this, in 1791, the US has its first Amendment to the Constitution enshrined, stating that: "Congress shall not enact any law establishing a religion, or prohibiting the free exercise of worship; nor will it restrict freedom of speech or the press; or the right of the people to assemble peacefully, or to petition the government for the correction of injustices". ${ }^{14}$

From the analysis of this first amendment, two clauses emerge: the first, establishment clause: which separates the religious confessions from the State, that is, the US Congress is prevented from legislating with the objective of establishing an official religion in the United States. In turn, the second clause, free exercise clause, guarantees the right to religious freedom, prohibiting the free exercise of cults ${ }^{15}$.

Thus, in the USA, there was a blind rupture of the European model, where religion and the State were not separated, bringing, now, in the American mold, the freedom of belief and of placing God as a major reference was observed and respected. Notwithstanding this neutrality of the State, there is now a need for the State not only to be neutral, but active in the observance of respect for the numerous denominations arising from free conscience. ${ }^{16}$.

It then moves on to the study of how the positivisation of religious freedom took place in Brazil and its historical setbacks.

\section{Arrival in Brazil}

It is almost unanimously agreed that Brazil, in the matter of postulating material rights, was long overdue. Instead, it used as a basis for internal affirmation of rights texts and legal studies from the external world. Thus, it is important to bring this topic as the application of religious freedom and its legal substitute.

The development of religious freedom in Brazil took place in a not so quick way, since Portugal, together with its crown, had a strong relationship with Roman Catholicism. Nevertheless, the discovery of Brazil itself had a significant incentive from the church as a way not only to expand the Portuguese market, but also to propagate the Roman Catholic apostolic religion. ${ }^{17}$.

As Padre António Vieira points out in his work:

Other men by divine institution have only the obligation to be Catholic: the Portuguese have the obligation to be Catholic and apostolic; other Christians have an obligation

\footnotetext{
${ }^{13}$ Bergara \& Gonçalves (2008) at 02.

${ }^{14}$ Brega Filho \& Alves (2009) at 76.

${ }^{15}$ Morais (2012) at 230.

${ }^{16}$ Teraoka (2010) at 24.

${ }^{17}$ Casamasso (2010) at $6167-6168$.
} 
to believe the faith, the Portuguese have an obligation to believe it, and more to spread it. $^{18}$

Moved by this maxim of dissemination of belief, the Portuguese pour into the ocean in search of the faithful, having found, in Brazil, "ignorants" capable of being easily catechised. In this way, the church helped the State to colonise the population of Brazilian lands, and in return, it attracted more faithful to its Catholic jurisdiction, with adherents of other faiths being subjected to the "holy inquisition", completely lacking the figure of religious freedom in, until then, colonial Brazil ${ }^{19}$.

This time, Brazil reaches its Proclamation of Independence loaded with political-religious values and ideals in the European mold. Likewise, more or less a year since the proclamation, the Emperor Dom Pedro I, on March 25, 1824, promulgates the Imperial Constitution, the first constitution in Brazil that brought liberal and authoritarian principles in its legal body ${ }^{20}$.

In a way, there is an advance in the promulgation of this Constitution, as it allowed the practice of cults as long as they did not exceed the limit of their activity. Otherwise, the promulgated Constitution ratified the Catholic religion as the main one of the Empires, in its 5th article, which said: "Art. 5th. The Roman Catholic Apostolic Religion will continue to be the religion of the Empire. [...]"21 . That is, even allowing a certain freedom of belief, it ensured the Empire's religion as supreme among the others, prospering, in any case, the aforementioned authoritarian principle ${ }^{22}$.

That said, there was no need to talk about total religious freedom until the year 1890 , since there is a very important historical milestone to trigger once and for all the protection of religious freedom in Brazil. It is Decree No. 119-A, of January 7, 1890, written by Ruy Barbosa and granted in the government of Marshal Deodoro da Fonseca, which prohibited the State from intervening in matters of religious matters, also extinguishing the patronised ${ }^{23}$ as described in art. 4 of the legal diploma: "Art. 4th The patronage with all its institutions, resources and prerogatives is extinguished". ${ }^{24}$

In this regard, it is important to bring up the first article of the aforementioned Decree which says:

Art. 1 The federal authority, as well as that of the federated States, is prohibited from issuing laws, regulations, or administrative acts, establishing any religion, or prohibiting it, and creating differences between the inhabitants of the country, or in services supported at the expense of the budget, for reasons of beliefs, or philosophical or religious opinions ${ }^{25}$.

\footnotetext{
${ }^{18}$ Vieira (2003).

${ }^{19}$ Bergara \& Gonçalves (2008) at 02.

${ }^{20}$ Casamasso (2010) at 6167

${ }^{21}$ Constituição (1824).

${ }^{22}$ Morais (2012) at 230.

${ }^{23}$ Morais (2012) at 234.

${ }^{24}$ Decreto $^{\circ}{ }^{119-A}$ (1890).

${ }^{25}$ Decreto ${ }^{\circ}$ 119-A (1890).
} 
that Brazil was already taking a big step towards state secularism, since the Magna Carta promulgated in 1891 brought a series of rights and prerogatives that totally separated religion and the State, dismantling the supreme religion of the empire and protecting the several existing religions. It is easy to notice this in the reading of article 11, paragraph 2 of the referred law, which prohibits embarrassment to figures by the public authorities.

From that point on, all the supervening Constitutions covered, in their text, the protection of religious freedom, and the current Magna Carta (1988) further expanded this national guarantee, no longer being subordinated to public order and good customs. It is noted that, even with all these historical advances in the protection of freedom of belief and belief, endless debates are still launched today about the real effectiveness of the legal text, since there is a dilemma and legal fissure about whether the State activity, in face of guarantee religious freedom, must be positive or negative. ${ }^{26}$.

In this step, it is important to analyse the next topic when it comes to state secularity, since it is essential, for this research, the real assessment of the position that the state exercises in relation to disputes arising from the correlation between rights and religion.

\section{State Secularity}

The State, as already mentioned, employed a series of protective norms for freedom of conscience and belief, embodying the Constitution in force and having its concepts and determinations widely respected. Nevertheless, it is necessary to emphasise the difference between conscience and belief, since they are not confused for dogmatic purposes, since a free conscience can be based on the will not to adopt any belief, and only the adherence of moral values and spiritual, not necessarily passing through to a concrete religion ${ }^{27}$.

In this way, the Constitution of 1988 lists in its text three distinct freedoms (conscience, belief and worship), even though they are different from each other, they have a degree of correlation:

Art. 5 (VI) - the freedom of conscience and belief is inviolable, the free exercise of religious cults being guaranteed and the protection of places of worship and their liturgies guaranteed, in accordance with the $\operatorname{law}^{28}$.

Thus, analysing the legal text exposed above, it is easily possible to notice that the constituent brought a greater scope in the protection of fundamental freedoms. Freedom of belief refers to the freedom of the individual to choose their religion or religious sect, as well as their right to change or leave any religion, having the power to choose not to adhere to any religion. freedom of disbelief, protected by

\footnotetext{
${ }^{26}$ Casamasso (2010) at 6169.

${ }^{27}$ Brega Filho \& Alves (2009) at 80.

${ }^{28}$ Constituição (1988).
} 
the law which gives the individual the prerogative of, if he wishes, not to be bound by any religion, such as atheists ${ }^{29}$.

There is no need to misinterpret that such freedom, as it is constitutionally guaranteed, is absolute. Now, let it be said in passing, that nothing in law is absolute, not being, in this way, religious freedom. It happens that it can be "violated", contrary to the legal provision, if it causes damage to public order or, even, if its cults harm any other principle or legal norms in force.

In the second part of the same highlighted item, there is the protection of places of worship and their liturgies, and, unlike the first constitution in the Brazilian imperial period in which services could only be held in specific places, now, the practice of religion can be done in public or private places, being penalised by the penal code whoever hinders such right, as it appears from article 208 of the Penal Code in force, in verbis:

Art. 208. To mock someone publicly, for reasons of religious belief or function; prevent or disturb ceremony or practice of religious worship:

Penalty - detention, from 1 (one) month to 1 (one) year, or fine.

Single paragraph. If there is use of violence, the penalty is increased by one third, without prejudice to that corresponding to violence ${ }^{30}$.

In view of this, for there to be an effective observance of the listed fundamental freedoms, the State cannot, or should not, be linked to any religion. Such bond being formally prohibited since Decree No. 119, of January 17, 1890, bringing the real separation of State and Church, establishing the lay or lay State, in its abstentionist character ${ }^{31}$.

In this sense, Jorge Miranda (2014) brings the concept of secular State, defending the negative obligation of the State:

Secularity means not assuming religious tasks by the State and neutrality, without preventing the recognition of the role of religion and the various cults. Secularism means distrust or rejection of religion as a community expression and, because it is imbued with philosophical or ideological assumptions (positivism, scientism, free thought or others), it ends up calling into question the very principle of secularism (...).

In this way, the theory of State secularity proclaims the autonomy of different and different religions, restricting the positive activity of public authorities when it comes to religious confessions. However, having such religions placed on the same level of equality, they can exert political influence within the limits and proportions of their social burden. The lay state does not profess, does not indicate, does not determine ${ }^{32}$.

Therefore, the lay State of this safeguard the associations linked to religious activity, preserving the autonomy of the churches in relation to their activity and

\footnotetext{
${ }^{29}$ Brega Filho \& Alves (2009) at 79.

${ }^{30}$ Decreto-lei no $^{\circ} .848$ (1940).

${ }^{31}$ Brega Filho \& Alves (2009) at 79.

${ }^{32}$ Brega Filho \& Alves (2009) at 80.
} 
protestant exercises. Likewise, the relative separation between the State and religion is guaranteed, since it is not absolute due to the still imminent duty of the State to ensure the observance of individual rights and freedoms listed in the Federal Constitution $^{33}$.

These rights, to adhere to a religion or not, can also be seen, for example, in the International Covenant on Civil and Political Rights, where it states in its art. 18, al. 2 that "No one may be subjected to coercive measures that may restrict their freedom to have or to adopt a religion or belief of their choice". From this comes the total prohibition of the inquisitorial power on the part of the State in making someone adopt, on a compulsory basis, a certain religion ${ }^{34}$.

In the conception of Marli Eulália Port, the existing separation between churches and the State perfectly allows for free competition between churches (which is not intended to be discussed here) and prevents the hegemonic predominance of a single religion.

Thus, the same author brings the idea defended by Thomas Jefferson, who lectures as follows:

(...) the intervention of the state as coercion would only be justified in those cases where it was a question of making the constitutionally established rights and duties enforceable or of protecting the rights of third parties. These religious freedom influences were felt in the Virginia Bill of Rights.

In this tuning fork, the principle that guides the separation of church and state would constitute a negative competence, with certain situations of fact and law beyond the reach of state interference.

In view of this, what can be seen today is a tireless struggle in favor of social union, since there is no concrete religious base in general, capable of bringing this unity. Which is more than certain, since differences, in this sense, place democracy as supreme, relying then on the principles of justice, reciprocity and dialogic constitutionalism to settle religious conflicts ${ }^{35}$.

Even though the State is secular, and society is secularised, it must be recognised that both can be influenced by religious factors. Of course, noting the need to reconcile religious factors with positive freedoms, not taking into account the conviction of each one. That is, even though they are part of a secular environment, the protection of God is real, in a way, by the State ${ }^{36}$. It is possible to note this in Article 5, items VII and VIII of the Federal Constitution, which states that:

VII - it is ensured, under the terms of the law, the provision of religious assistance in civil and military entities of collective detention;

VIII - no one shall be deprived of rights for reasons of religious belief or philosophical or political conviction, unless he invokes them to exempt himself from the legal

\footnotetext{
${ }^{33}$ Morais (2012) at 230.

${ }^{34}$ Brega Filho \& Alves (2009) at 80.

${ }^{35}$ Port (2003) at 20.

${ }^{36}$ Port (2003) at 20.
} 
obligation imposed on everyone and refuses to comply with an alternative provision, established by law; $(. . .)^{37}$.

The assistance, which stands out in the first item mentioned above, must be provided to a list of people who are in the establishments of civil entities, such as hospitals; and in military establishments, such as prisoners, and minor offenders. Thus, religious assistance serves as a psychological subterfuge capable of speeding up the intern's recovery time. As for the sick, it also serves as a mental way of providing hope capable of reflecting on physical improvement, reducing suffering and tension ${ }^{38}$.

In this tuning fork, even though religious assistance is beneficial, in most cases, when used. There is no need to talk about the obligation of this assistance, since, if imposed in a mandatory way, it would be contrary to the constitutional text itself and, also, would be hurting the theme discussed here, religious freedom ${ }^{39}$.

Already in item VIII above, brings to light the excuse of conscience in which the non-performance of legal duties in respect of religious convictions is allowed. Of this, for example, we can mention the individual who does not do military service because he is not compatible with their religious dogmas. On another screen, there are alternative services that are compatible with the state's need and respect for the individual's creed and, having the individual denied the provision of the legal obligation and therefore also denying the provision of the alternative obligation, he will suffer the consequences provided for in article 15, Item IV, of the Major Law, which imposes the loss or suspension of political rights ${ }^{40}$.

Under this bias, it is certain that secularity plays a role in which it will fluctuate according to the political context in which it is inserted, depending on the degree of secularisation of each society. This is inferred from the legal advances that the protection of belief has obtained over the years and also from the process of state secularisation ${ }^{41}$.

It is noted that all terms previously used that are linked to religious freedom (belief, conscience, creed, worship) work in a dialectical manner, that is, when any of them is no longer protected, it directly compromises constitutional supremacy, placing the religious freedom podium in fundamental rights ${ }^{42}$.

From this, it is possible to say that the State protects the individual's right to self-determination, and the cult, or specific rite, is the way in which the protected object seeks his or her postulated right. Duguit (2005), dealing with this, states that:

(...) every religion contains a second element: the rite or cult. For religious freedom to exist, everyone must be entirely free to practice any religious cult, that no one can be harmed by it, nor prevented, directly or indirectly, from practicing the cult

\footnotetext{
${ }^{37}$ Constituição (1988).

${ }^{38}$ Bergara \& Gonçalves (2008) at 07.

${ }^{39}$ Bergara \& Gonçalves (2008) at 08.

${ }^{40}$ Bergara \& Gonçalves (2008) at 08.

${ }^{41}$ Borges \& Alves (2013) at 234.

${ }^{42}$ Brega Filho \& Alves (2009) at 81.
} 
corresponding to their religious beliefs, and the reverse . $[\ldots]$ religious freedom is, therefore, seen in this way, essentially freedom of worship.

The State, therefore, should not remain inert in the face of the issue, but, in a concise and coherent manner, act objectively seeking the real protection of the rights listed in the Constitution. The State must provide and allow that the duties arising from each religion are respected, not talking about "cesaropapism" (in which political power dominates the religious) but an authentic democratic State of law. Thus, if the State, despite granting laws that protect the individual belief of each one, imposes conditions that prevent them from practicing that same belief fully, it will not speak of religious freedom ${ }^{43}$.

It is important to bring up Article 12 of the American Convention on Human Rights, which provides:

Article $12(\ldots)$

$\S 1$. Everyone has the right to freedom of conscience and religion. This right implies the freedom to retain one's religion or beliefs, or to change religion or beliefs, as well as the freedom to profess and disclose one's religion or beliefs, individually or collectively, both in public and in private.

$\S$ two. No one may be subjected to restrictive measures that could limit their freedom to retain their religion or beliefs, or to change their religion or beliefs.

$\S 3$. The freedom to manifest one's religion and beliefs is subject only to the limitations provided for by law and which are necessary to protect the security, order, health or public morals or the rights and freedoms of others.

$\S 4$. Parents and, where applicable, guardians, have the right to have their children and pupils receive a religious and moral education that is in accordance with their own convictions. ${ }^{44}$.

In this way, the State, in safeguarding the right to religious freedom, is not based on passivity, it does not consist in complete omission, since a State that is totally silent is an enemy of religious freedom. On the contrary, the State is required to cooperate, without ideological or religious proselytism, with the aim of defence and protection, providing everyone with real freedom to exercise their religion. Thus, it would be correct to say that a secular State is not expected, but a religiously neutral State that, by this neutrality, can dismiss legal, cultural and social conflicts involving religious freedom without, for this, being completely silent $^{45}$.

Now, insofar as it is stated that the State must not be entirely secular, it is necessary to ensure, in another way, that the State must be completely neutral, this neutrality being, as already mentioned, absolute. Absolute in the sense that there is no discrimination, on the part of the State, between the various religions and temples, whether for their benefit or harm, thus prospering the equality of treatment ${ }^{46}$.

\footnotetext{
${ }^{43}$ Borges \& Alves (2013) at 235.

${ }^{44}$ Decreto $^{\circ} 678$ (1992).

${ }^{45}$ Brega Filho. \& Alves (2009) at 85.

${ }^{46}$ Vieira (2003) at 86.
} 
Here, the principle of "treating equals equally and unequal in proportion to their inequality" is fully applied, given that unequals considered as minorities must have an equal treatment, with the State, through its three powers, legislate, judge and execute actions that protect such minorities.

In this wake, Vladimir Brega Filho ${ }^{47}$ :

It could be argued that this "unequal" treatment could lead to confrontation, to religious sectarianism. Just the opposite is believed. Unequal treatment aims to guarantee all constitutionally guaranteed rights, promoting the inclusion of all people, regardless of their religion.

From this, it is clear that only through regulation by law, with regard to competitions, entrance exams, etc., it is possible to eradicate discrimination and social exclusion of followers of minority religions and beliefs. Here comes the idea of democracy, since it is not limited to the act of governing for the majority in that, in this step, it encompasses a space in which a diversity of different views in a political community behaves. ${ }^{48}$.

In this step, even if one of the views prevails over the other, it is essential that the State, as a presupposition of minimum action, diversity, the common reference and the equality of conditions that provide, any creed, to participate in this multiple political space ${ }^{49}$.

Therefore, it is possible to observe an existing conflict in the case of public examinations, school activities and entrance exams, where the day keeps and the right to believe is strongly debated when such acts are put to the test. It is observed that the lack of strict regulation on such guidelines brings serious harm to those who profess minority religions, and therefore it is not reasonable to require them to renounce their faith to adjust to the broadly comprehensive constitutional dictates. ${ }^{50}$.

Guard day is, if not the most important, one of the basic principles of many religions. Once you take for yourself, based on the bible or sacred texts, a preconceived day to worship and respect the rituals of each creed. As an example, Roman Catholic Apostolics keep Sunday, as defined by John Paul II in Dies Domini in 1998; Seventh-day Adventists keep the Sabbath (Jewish shabbat); Muslims, Friday; among other religions of which it has its own guard days ${ }^{51}$.

Note the great repercussion that this issue has caused, generating friction precisely by guarding these days when determining reasons for dismissal from work, exams and military service ${ }^{52}$.

\footnotetext{
${ }^{47}$ Brega Filho \& Alves (2009) at 75-94

${ }^{48}$ Martins \& Mituzani (2011) at 322.

${ }^{49}$ Martins \& Mituzani (2011) at 345.

${ }^{50}$ Bergara \& Gonçalves (2008) at 15.

${ }^{51}$ Bergara \& Gonçalves (2008) at 16.

${ }^{52}$ Chiassoni (2017) at 260.
} 


\section{Religious Isonomy and Seventh-day Adventists}

In this topic, the relational analysis of religious isonomy against the freedom of belief of Seventh-day Adventists will be made. The choice was based on recent major judgments involving Adventists that have had great repercussions. However, it is noted that over time they have gained expressive rights for the full exercise of their faith, as will be shown.

In this compass, religious isonomy is a very old term already included in some legal texts, as mentioned in topic 1 of this research. Refreshing the memory, this principle is observed in the Universal Declaration of Human Rights of 1948, in its article II, 1; in the American Declaration of the Rights and Duties of Man, also dated 1948 and, finally, it is also possible to observe in article 5 of our Magna Carta this principle instilled in a generic way ${ }^{53}$.

The study of isonomic treatment is complex, as it refers to the role of the State (Law and Law) to eradicate unequal treatment. However, it is important to emphasise the characteristic of the fundamental rights listed in the Federal Constitution, considered as "optimisation commandments" since it defends the analysis and factual support in a broad way, defending each situation in the screen in the most concrete way possible. ${ }^{54}$.

It is important to bring up what Thiago Massao Cortizo Teraoka:

Thus, isonomy does not prohibit the occurrence of distinctions between individuals; however, it forbids unreasonable distinctions. The discretion to be elected cannot be unreasonable or prohibited by the Constitution. In this thinking, any distinction not allowed by the constitutional text should not be admitted. At this point, the religious option is not elected by the Constitution as a possible criterion for discrimination. ${ }^{55}$

It is noteworthy then that, in theory, there should be no distinction based on the religion of each individual, except for constitutional provisions that allow it, such as the conscientious objection observed in the military enlistment. Even so, regarding this exemption from military service, as already discussed in topic 2 of this work, the conscientious objector will have the duty of alternative services provided for in $\mathrm{Law}^{56}$.

Data venia, the church, having in its institutional scope a regulatory character of rights and duties, like the Law itself; it can create some antagonisms with its internal rules and the legal system itself. The example prism is polygamy; ritual animal sacrifice and drug use in a religious context. In this way, creating untutored rights ${ }^{57}$.

On the other hand, it is also possible that religions restrict Rights which the legal system itself does not prohibit. Taking as an example the prohibition of blood transfusion and eating certain types of food. It is in this antagonistic context that

\footnotetext{
${ }^{53}$ Teraoka (2010) at 143.

${ }^{54}$ Martins \& Mituzani (2011) at 325.

${ }^{55}$ Teraoka (2010).

${ }^{56}$ Morais (2012) at 246.

${ }^{57}$ Teraoka (2010) at 145.
} 
the maxim of differentiated treatment for some religions emerges, or rather, for the individual/collective exercise of freedom of belief ${ }^{58}$.

Thus, it is possible, in Brazil, a differentiated treatment based on conscientious objection. However, there is a legal barrier when it comes to legal equality, since it is necessary to regulate, in a concrete way, exceptions that aim to untangle the current repetitive litigations in the religious theme ${ }^{59}$.

In view of this, in order for there to be a differentiated treatment, it is necessary to weigh factors that are important to gauge the real need to impose exceptions. As, for example, the importance that religion and faith have for the believer; the importance of the legal asset protected by the Law and, finally, the consideration, based on reasonableness, of opposing legal assets. In other words, in the absence of the Law, as an exception and not a rule, differential treatment for religious reasons is allowed when restrictions on religious freedom are disproportionate to the protected legal interest ${ }^{60}$.

It should be noted that the aforementioned conscientious objection refers to legal law (protection by law) and not to unlawful facts that, in this way, are not under the aegis of the Constitution. In this, says Taraoka that "the conscientious objection is the waiver of a certain obligation imposed by general law. They are exceptions, generally based on religious motives, with the objective of making an exception for a legal command" 61 .

On this mat, there is a dispute when the day of guard (rest) is put on the agenda. For the most part, existing religions keep either Saturday or Sunday, with Seventh-day Adventists keeping that. It so happens that the Federal Constitution, correctly, does not determine any official day of custody, thus observing its abstentionism in the matter. However, in article 7, item XV thereof, the constituent power placed, preferably, the day of rest on Sunday ${ }^{62}$.

The problem arises when, when speaking of Adventists, they are put to the test at public exams, exams, work and entrance exams on the sacred day, since they refuse to take the exam or exam when it falls on Saturday. Thus, there is a need for unequal treatment, but in a reasonable way, with the aim of, through unequal treatment, ensuring equality.

In this ball, the Sabbatarians had a great victory when the days of ENEM were changed to two consecutive Sundays, differing from the previous model which concerned only one weekend, with the tests being held on Saturday and Sunday. Before, they had their right of belief respected, being able to start taking the exam only after sunset on Saturday, however it was necessary to wait inside the room, which caused great discomfort. ${ }^{63}$.

In this way, precedents judged, as will be shown in the next topic, has already been pacifying the idea that, not harming the public event, nor the other candidates and, still, not generating a financial loss to the public purse, it is possible to make

\footnotetext{
${ }^{58}$ Teraoka (2010) at 146.

${ }^{59}$ Chiassoni (2017) at 272.

${ }^{60}$ Teraoka (2010) at 148 .

${ }^{61}$ Teraoka (2010) at 147.

${ }^{62}$ Chiassoni (2017) at 273.

${ }^{63}$ Bergara \& Gonçalves (2008) at 16.
} 
the day more flexible of the exams, that is, to attend the right of belief of the Sabbatarians. In other words, if there is no chance of damage, nor injuring the rights of other candidates, the right to religious freedom must be maximised ${ }^{64}$.

From this, it is observed that, even being a minority religion, as discussed above, they have a relevant number of faithful, since Sabbath observing is not limited only to Seventh-day Adventists, with many other religions in Brazil having adopted this unavailable duty, such as the Jewish community; Seventh-day Baptist Church; Promise Adventist Church and more ${ }^{65}$.

It is worth bringing up State Law of São Paulo No. 12,142, of 12/08/2005, which discusses public examinations, entrance exams and the rights of students enrolled in public and private schools:

Article 1 - The public examinations or selection process for filling public positions and the entrance exams of public and private universities will be held from Sunday to Friday, between 8:00 am and 6:00 pm.

$\S 1$ - When the promotion of contests in accordance with the "caput" is unfeasible, the organizing entity may hold them on Saturday, and must allow the candidate who alleges a reason for religious belief the possibility of doing them after $6 \mathrm{pm}$.

$\S 2$ - The permission referred to in the previous paragraph must be preceded by a request, signed by the interested party, addressed to the organizing entity, up to 72 (seventy-two) hours before the opening time of the event.

$\S 3$ - In the case of $\S 1$, the candidate will be incommunicado from the regular time provided for the exams until the beginning of the alternative time previously established for him.

Article 2 - It is assured to the student, duly enrolled in public or private educational establishments, of elementary, middle or higher education, the application of tests on days that do not coincide with the period of religious custody provided for in the "caput" of article 1.

$\S 1$ - The student may, for the same reasons provided for in this article, request that the school, in substitution for their presence in the classroom, and for the purposes of obtaining attendance, be assured, alternatively, the presentation of a written work or any other academic research activity, determined by the educational establishment, observing the curricular parameters and lesson plan of the day of your absence.

$\S 2$ - The requests referred to in this article will be mandatorily accepted by the educational establishment.

In this sense, the cases in which the Law regulates the form of protection for religious minorities are rare, being found in some states, such as in the case of São Paulo, the protection of the conscience rights of candidates who abstain from performing acts on their day of guard.

It is important to note that the day of guard also reflects in the labor sphere, when the hired Sabbatarian is faced with the obligation to work on Saturdays. However, it is clear that the constitution gave preference to Sunday as a day of rest, and it is not the employer's obligation to grant the employee a day of rest on Saturday. However, analysing article 1 of Law n.605 of January 5, 1949, which is still in force, we have that: "Art. 1st Every employee is entitled to weekly paid rest

\footnotetext{
${ }^{64}$ Teraoka (2010) at 155.

${ }^{65}$ Teraoka (2010) at 157.
} 
for twenty-four consecutive hours, preferably on Sundays and, within the limits of the technical requirements of the companies, on civil and religious holidays, in accordance with local tradition ${ }^{66}$."

It appears from this that the possibility of negotiation between employer and employee on the subject is fully applicable, constitutionally and infra-legally, and the absence of the employee associated with a minority religion in his/her day of custody is admissible, provided that, for this, it is made the proper recompositing and does not cause inconvenience for the company ${ }^{67}$.

Finally, it should be concluded that, since there is no legislative solution to settle disputes or differences in the issue of protecting religious freedom, it is perfectly up to the judiciary to use its prerogatives and powers to regulate, through judgments and jurisprudence, this extremely important right for a society mostly believer.

Now, the analysis of judgments on the theme of religious freedom and the day of custody of Seventh-day Adventists is turned. It is important to bring up recent judgments of the Federal Supreme Court and the content of the votes given during the judgments.

\section{Analysis of the Votes of the Ministers in Extraordinary Appeal No. 611,874 and Interlocutory Appeal in Extraordinary Appeal No. 1,099,099}

In this topic, two processes that ran before the Supreme Court and were res judicata will be analysed. The subject is freedom of belief and the exercise of religion and belief of two people who had their rights curtailed for alleging exception of belief in which, in the first process $(611,874)$, an Adventist candidate's search for an evaluation is noted. For entry into public office on a date and time different from those established in the competition calendar.

In this way, in the second process $(1,099,099)$, the search for her rights refers to a public teacher, also an Adventist, who was in the probationary stage and was exonerated for excessive absences at sunset on Friday at sunset on Saturday, claiming that he cannot work on those days because it is, within the Adventist belief, the day of guarding and rest, even if he is willing to work in alternative hours.

Thus, for the principle of analysis, it is worth bringing up, first, the amendment of this case, which has Minister Edson Fachin as Rapporteur. If not, let's see:

SUMMARY: Constitutional. Administrative. Freedom Of Consciousness And Belief. Seventh Day Adventist. Magistry. Night Day. Friday. Credit Hours Compliance. Fail In Probattory Stage. 1. The constitutional issue regarding conscientious objection, for religious reasons, is endowed with general repercussion as a justification for generating the administrator's duty to provide an alternative obligation for public servants, in a probationary stage, to fulfill their functional duties. 2. General repercussion of the recognised constitutional issue.

\footnotetext{
${ }^{66}$ Teraoka (2010) at 158.

${ }^{67}$ Teraoka (2010) at 165 .
} 
(ARE 1099099 RG, Rapporteur: EDSON FACHIN, Full Court, judged on 12/13/ 2018, ELECTRONIC PROCESS DJe-048 DIVULG 03-11-2019 PUBLIC 03-12$2019)^{68}$.

The cases in question were judged together, given their degree of similarity to each other. However, it is important to highlight the votes of some specific ministers, such as the Rapporteur, Minister Edson Fachin, and the vote of Minister Dias Toffoli, since he is totally against the rescheduling of tests and the flexibility of working hours under the allegation of excuse of conscience.

Minister Dias Toffoli maintains that "Although the Federal Constitution protects the freedom of belief and conscience, at no time does it prescribe the state's duty to promote conditions for the exercise or access to the determinations of each religious belief." Still, it claims that this differentiated treatment would harm the principle of isonomy, bringing an even greater burden to the public administration.

However, it is noted that this understanding goes against the constitutional precepts, since in article 5, item VIII of our Magna Carta, it prohibits the deprivation of rights for reasons of religious belief and, also, since the author was willing to comply alternative provision, this could not be denied.

The newest minister of the house, Nunes Marques, had the same understanding, proclaiming that the State, as a lay person, should not impose the duty of the administration to carry out differentiated treatments based on faith. It argues that:

Freedom of belief imposes the recognition that each person has the domain of their religious trajectory and of taking the necessary measures to implement their life projects. If, on the one hand, everyone must be free to believe as they wish, this does not mean that the State should associate itself with the same beliefs and, with unpredictable consequences, be compelled without provision by law to create alternative means in order to meet the restrictions of the more diverse religious commandments.

In this way, trying to discharge the State, erroneously, from striving for equality, even when it is necessary to impose an inequality to do so. It is noted that the State, making this distinction in favor of equality, is not allying itself with any belief, but, contrary to popular belief, crystallizing the full exercise of isonomy, which is the duty of all component spheres of the State body.

Following the two ministers in this same thinking, minister Dias Toffoli maintained, even though there is no duty of the administration to provide alternative benefits for public servants in a probationary state under the bias of their excuse due to religious conscience. However, it is up to the administration, since there are no positive rights that oblige it to do so, to assess the public interest and the interest of the public servant to grant such rights.

In this sense, binding the candidate fully to the notice of competition would not be a way to exercise the right to equality. Since, even if the candidate adheres to all the facts of the notice, this document could, as in this case, restrict his full

\footnotetext{
${ }^{68}$ Supremo Tribunal Federal (2018).
} 
rights as citizens, directly confronting paragraph 2, article 12 of the American Convention on Human Rights - Pacto San José from Costa Rica, which says:

Art.12 (...)

2nd. No one may be subjected to restrictive measures that could limit their freedom to retain their religion or beliefs, or to change their religion or belief'.

It is then noted that, if an obligation of the State is imposed on the citizen to choose between his work and his faith, there would already be an injury to the rights of such citizen, since it would be forcing him to choose between food support or sustaining you spiritually.

In this interregnum, as mentioned above, it is necessary to bring up the summary of process number 611,874 , which had the same votes as the process highlighted above. In this way, the votes in favor of religious freedom are now highlighted. If not, let's see:

CONSTITUTIONAL AND ADMINISTRATIVE LAW. WARRANTY OF SAFETY. PURPOSED AUTHORISATION TO CARRY OUT A PUBLIC TENDER STAGE AT A DIFFERENT TIME FROM THE TIME DETERMINED BY THE ORGANIZING COMMITTEE OF THE CERTAM BY POWER OF RELIGIOUS BELIEF. CONSTITUTIONAL PRINCIPLES IN CONFLICT. RECOGNISED GENERAL REPERCUSSION. MERIT. VIOLATION OF THE RIGHT OF EQUALITY. FEATURE NOT PROVIDED. 1. The constitutional fabric must move away from the idea that state secularity, understood as its non-confessional nature, implies abstention from religious issues. After all, to constrain the person in order to lead him to renounce his faith represents disrespect to the diversity of ideas and to the spiritual diversity itself. 2 . In the debate about the adequacy of administrative activities to alternative hours in respect of religious convictions, the State must implement positive benefits that ensure the full experience of religious freedom, which are not only compatible, but also recommended by the Constitution of the Republic, pursuant to item VII of art. 5, CRFB, which ensures the "provision of religious assistance in civil and military entities of collective detention", as well as art. 210, $\S 1, \mathrm{CRFB}$, which provides that "religious education, with optional enrolment, will constitute a discipline in the normal hours of public elementary schools. 3. The separation of Church and State cannot imply the isolation of those who keep a religion to their private sphere. The principle of secularism is not to be confused with secularism. The State must protect diversity, in its widest dimension, among which I include religious freedom and the right to worship. The limit to the exercise of such right is in the constitutional text itself, under the terms of item VI of art. 5th. 4. The setting, for reasons of religious belief of the candidate in a public examination, of an alternative date and/or time to carry out stages of the competition must be allowed, within reasonable limits, after prior and substantiated manifestation of conscientious objection by religious reasons. It is a practice to be adopted by the State, as it represents the implementation of the exercise of religious freedom without prejudice to other fundamental rights. 5. Extraordinary appeal not granted, establishing the following thesis: "In accordance with art. 5, VIII, of the CF, 
(RE 611874, Rapporteur: DIAS TOFFOLI, Rapporteur for Judgment: EDSON FACHIN, Full Court, judged on 11/26/2020, ELECTRONIC PROCESS DJe-068 DIVULG 04-09-2021 PUBLIC 04-12- 2021) ${ }^{69}$.

Due to the obligation of the State to provide different tools for the protection of freedom of conscience, Minister Edson Fachin defended the right of citizens who previously and justified their excuse of conscience to reach alternative times and days before the administration, both in exams and for activities in probationary stage. It maintains that "The administrator must offer alternative obligations so that religious freedom is ensured to the server in a probationary stage."

In this tuning fork, the other ministers followed Edson Fachin's thinking, but with limitations, that is, even the public power is not linked to dogmas and religious calendars, it could not be short-sighted in the face of injuries and suppression of basic rights guaranteed to all, which includes the religious minority in question.

Thus, Minister Luís Roberto Barroso, in a more precautionary view, protested the fact that it is necessary for the State to promote alternative ways of holding the public examination at a different time or date, as well as providing it to the official in probationary internship under discussion, reasonable alternatives for your work, provided that it does not generate a disproportionate burden to the public administration and also does not interfere with the isonomy of the existing case.

It is worth bringing up the phrase of Minister Rosa Weber, when she stated: "The State is separated from religion, but human beings are not separated from faith". Thus, the purpose of the two cases was partially done, not recognizing the existence of a subjective right for the authors, but, in another way, ratifying the State's obligation to equalise religious minorities and respect, in a coherent way, the seriousness of belief of each one, as we can infer from the menu highlighted above: "After all, to constrain the person in order to lead him to renounce his faith represents disrespect to the diversity of ideas and to the spiritual diversity itself."

It can be seen then that the majority votes were not just in favor of religious freedom. The votes were against the observance of constitutional guarantees that extend to minorities, since they need greater support and protection, making the State, through positive attitudes, fleeing from inertia, guarantee the equality protected by the Magna Carta.

\section{Conclusion}

The institute of religious freedom, concretely instilled in the individual freedoms protected by the Constitution, over time has made significant advances in its understandings and judgments. Importance is given when one sees the vast types of religions in which the believing minority finds difficulties in exercising their full activity. Thus, it is imperative to emphasise from this work that the judiciary, in the absence of the legislature, must guarantee individual freedoms with the aim of aligning the rights of all.

\footnotetext{
${ }^{69}$ Supremo Tribunal Federal (2020).
} 
Unlike the State \& Religion relationship that existed in the past, where the inquisitive power was the guide for decisions. The sensory vector is now more present in diverse agendas that involve the rights of belief. It is important to remember the maxim transcribed in this work: "The lay State does not profess, does not indicate, does not determine", being certain that such State must profess, indicate and determine only in favor of equal and homogeneous rights.

However, state secularism is not limited to the state's inertia in relation to religious matters. It refers to its duty to be neutral in relationships involving faith and creed, since secularity denotes a totally negative activity by the State, removing its responsibility to resolve disputes involving matters of religion, which is seen as wrong, since in the face of inequalities, the State has the duty to guarantee equality, in a neutral way, weighing the values in question.

In this thinking, as seen, the courts have taken into account this neutrality, acting in a positive way to guarantee equal rights. It is noted, therefore, that the Adventist society received support as citizens, since the majority of ministers in the court decision decided for democracy and for not distinguishing citizens for reasons of belief and religious choices. What is right is, by the way, an obligation of the State.

That said, the present work proved to be relevant to evaluate, in a concrete way, the type of relationship that the State has with religion and its interference limits. As we have seen, the separation between the State and the Church is not at all absolute, and if there are abuses in the religious sphere or even suppression of rights in the private or public sphere, State activity is necessary.

\section{References}

Bergara, S.P.N. \& R.B.T. Gonçalves (2008). LIBERDADE RELIGIOSA. Revista do Programa de Mestrado em Ciência Jurídica da Fundinopi [In Portuguese]

Borges, A.W. \& R.V. Alves (2013). O Estado laico e a liberdade religiosa na experiência constitucional brasileira. Revista Brasileira de Estudos Políticos,

Casamasso, L.M.A. (2010). Estado, Igreja e Liberdade Religiosa na "Constituição Política do Império do Brazil", de 1824. XIX Encontro Nacional do CONPEDI realizado em Fortaleza, Fortaleza, p. 6167-6173, 12 jun. 2010. [In Portuguese].

Chiassoni, P. (2017). Liberdade de consciência e liberdade religiosa em um Estado Constitucional - O que visa proteger. Revista Jurídica da Presidência. [In Portuguese].

Duguit, L (2005). Manual de derecho constitucional. Granada: Comares, p. 232-233. [In Spanish].

Filho, B.V. \& F. Alves (2009). Da Liberdade Religiosa Como Direito Fundamental: Limites, Proteção e Efetividade. Revista do Programa de Mestrado em Ciência Jurídica da Fundinopi. [In Portuguese]. https://doi.org/10.9732/P.0034-7191.2013v 107p227. [In Portuguese].

Martins, A.C.M. \& L. Mituzani (2011). Direito das Minorias Interpretado: o compromisso democrático do direito brasileiro. Revista Seqüência, Santa Catarina [in potuguese]

Miranda, J. (2014). Estado, Liberdade Religiosa e Laicidade. Observatório da Jurisdição Constitucional. Ano 7, no. 1, jan./jun. 2014. ISSN 1982-4564. [In Portuguese]. 
Morais, M. E. P. (2011), 'Religião e direitos fundamentais: o princípio da liberdade religiosa no Estado Constitucional Democrático brasileiro' in Revista Brasileira de Direito Constitucional-RBDC n. 18

Neto, J.W. (2006). A edificação constitucional do direito fundamental à liberdade religiosa: um feixe jurídico entre a inclusividade e o fundamentalismo. Pontífica Universidade Católica do Rio Grande do Sul, Porto Alegre. [In Portuguese].

Port, M.E. (2003). Liberdade Religiosa numa Comunidade Constitucional Inclusiva: dos direitos da verdade aos direitos dos cidadãos. Coimbra Editora Limitada. In Portuguese].

Taraoka, T.M.C. (2010). A Liberdade Religiosa no Direito Constitucional Brasileiro. Doutorado, Faculdade de Direito da Universidade de São Paulo, São Paulo - SP. [In Portuguese].

Vieira, A. Padre (2003). Sermões, volume 1, São Paulo: Hedra. [In Portuguese].

Wermuth, M.Â.D. \& J.S. Schorrr (2017). Liberdade Religiosa e Sistemas Regionais de Direitos Humanos: Uma Análise a Partir de Casos Julgados pelo Tribunal Europeu e Pela Corte Interamericana de Direitos Humanos. Revista Direitos Sociais e Políticas Públicas (UNIFAFIBE), São Paulo, v. 5, n. 2, p. 817-146, 5 nov. [In Portuguese].

\section{Cases}

Supremo Tribunal Federal. (2018). Agravo em Recurso Extraordinário n. 1099099. Diário da Justiça, Brasília-DF. [In Portuguese].

Supremo Tribunal Federal. (2020). Recurso Extraordinário n. 611874. Diário da Justiça, Brasília-DF. [In Portuguese].

\section{Legialtion}

Constituição (1824)]. Constituição Política do Império do Brasil. Brasília, DF: Presidência da República. [In Portuguese].

Constituição (1988)]. Constituição da República Federativa do Brasil de 1988. Brasília, DF: Presidência da República. [In Portuguese].

Decreto ${ }^{\circ} 119-A$, de 7 de janeiro de 1890. Proíbe a intervenção da autoridade federal e dos Estados federados em matéria religiosa, consagra a plena liberdade de cultos, extingue o padroado e estabelece outras providencias. [In Portuguese].

Decreto-lei no 2.848 (1940). Institui o Código Penal. [In Portuguese].

Decreto $n^{\circ} 678$ (1992). Promulga a Convenção Americana sobre Direitos Humanos (Pacto de São José da Costa Rica). [In Portuguese]. 
